\title{
Inclusion strategy for mobile technology in the classroom: experience at the Universidad de Tarapacá
}

\author{
Estrategia de inclusión de tecnología móvil en el aula: \\ experiencia de la Universidad de Tarapacá
}

\author{
Hernando Bustos Andreu ${ }^{1} \quad$ Milagros Delgado Almonte ${ }^{2} \quad$ Liliana Pedraja Rejas $^{3}$ \\ Recibido 25 de noviembre de 2009, aceptado 17 de enero de 2011 \\ Received: November 25, 2009 Accepted: January 17, 2011
}

\begin{abstract}
RESUMEN
Diversos estudios muestran que la inclusión de Tecnologías de Información y Comunicación (TIC's) en educación es beneficiosa, sin embargo, se reconoce que es un proceso complejo y que para obtener buenos resultados debe ser debidamente planificado y estructurado. El presente artículo muestra la aplicación de una estrategia basada en un conjunto de planes de acción para la inclusión de una plataforma educativa de tecnología móvil en el aula. Los resultados obtenidos en esta experiencia realizada en la Universidad de Tarapacá permiten establecer que el proceso fue exitoso del punto de vista académico y se detectan nuevos imperativos que inciden en el proceso de inclusión.
\end{abstract}

Palabras clave: TIC's, tecnología educativa, inclusión de tecnología, educación superior, tecnología móvil, procesos de inclusión de tecnología.

\begin{abstract}
Despite the existence of recognized benefits of the use of information and communication technology in education, the employment of such technology is a complex process that needs appropriate planning and structuring to obtain good results. This article shows the results obtained from the application of a consistent strategy to a set of action plans oriented to the incorporation of a mobile technology platform in the classroom. The results obtained in this experience at the Universidad de Tarapacá allowed us to establish that the process was successful with regard to the academic aspect and detect new imperatives for the inclusion process.
\end{abstract}

Keywords: ICT, educational technology, inclusion of technology, tertiary/higher education, mobile technology, technology inclusion processes.

\section{INTRODUCTION}

Nowadays it is recognized that the use of information and communication technology (ICT) in education is not only a useful tool for teaching purposes, but also a mechanism that provides students with the opportunity to use technologies and thereby prepare them to develop in today's society which is based on information, technology and competition [1].
Shirely Alexander [2] evaluated 104 projects of ICT use in higher education, and found the following types of benefits for students:

- Improved quality of learning

- Improved productivity of learning

- Improved access to learning

- Improved student attitude to learning

1 Escuela Universitaria de Ingeniería Industrial, Informática y Sistemas. Universidad de Tarapacá. Casilla 6-D. Arica, Chile. E-mail: hbustos@uta.cl

2 Comisión Nacional de Acreditación. Av. Ricardo Lyon 1532, Providencia. Santiago, Chile. E-mail: mdelgado@cnachile.cl

3 Escuela Universitaria de Ingeniería Industrial, Informática y Sistemas. Universidad de Tarapacá. Casilla 6-D. Arica, Chile. E-mail: lpedraja@uta.cl 
Despite the current emphasis on the use of ICT, and the pressure that teachers receive from diverse sources (professional associations, government bodies, parents, administrators, etc) to integrate ICT into teaching for the results that can be achieved [1], the level of use is low.

This low level of use can be explained by the fact that the incorporation of ICT in education is neither rapid nor simple [3]. Moreover, existing studies indicate that the implementation of technologies in education is complex [4] and that there are diverse factors that cause this. Some of these are described below:

1. Generally the origin of the process of incorporation of ICT is external to the pedagogical environment and includes concepts, discourses and practices from an unfamiliar technical context. This engenders resistance, distrust and lack of commitment [5]

2. Weakness in the use of technology and skills for integrating them in the instructional process. This leads teachers to feel unprepared for integrating technology in their classes and when they do, there are unexpected results. [4-8].

3. Availability and accessibility to technological resources. Technological resources are often scarce and based in laboratories rather than classrooms, complicating their access and availability $[6,9]$

4. Changes in practice and redesigning pedagogical activities. To maximize the results of the use of technology in educational processes, frequently involves changing the pedagogical focus and the strategy for administering the class with the aim of designing lessons that lead to improved learning. [4-5, 7-8].

From the above, it is stated that to obtained good results, including process technology must be properly planned and organized.

In the rest of this article, an experience carried out in the Universidad de Tarapacá will be presented which involved the carrying out of a pilot project for the inclusion of mobile technology in the classroom.

\section{PROJECT: MOBILE TECHNOLOGY IN THE CLASSROOM}

The Universidad de Tarapacá (UTA) is a state university in the extreme north of Chile in the city of Arica. It has an integrated vision - that sees the key to its competitive advantage as being in the talents and skills of people - and a humanist vision - that centers on the individual, developing him or her professionally and his or her knowledge, without social, ideological, ethnic or religious discrimination. These affect the aims of social mobility, developing awareness for the assurance of the regional ecosystem and its permanent vocation of contributing to regional development.

As such, one key axis for the consolidation of the development of the UTA is the realization of quality teaching. In this context of seeking to improve the quality of education, the university decided to explore the use of mobile technology as a support tool for the instruction and evaluation of course content. The technology used was an EDUINOVA (www. eduinova.com) platform developed by the Universidad Católica de Chile that consists in a laboratory of computers with a network of a local portable area that can be moved and used in any classroom that has an electric connection point. This laboratory comprises 50 pocket $\mathrm{PCs}$ with wireless connection through $802.11 \mathrm{x}$, a router to constitute a network, and two adapted suitcases that serve to transport the computers and large battery charger, as shown in Figure 1. This hardware platform has a set of ad-hoc developed software applications for the creation of a data base of educational content, generation of pedagogical activities and its application in the classroom according to a collaborative learning model. For more details see [10].

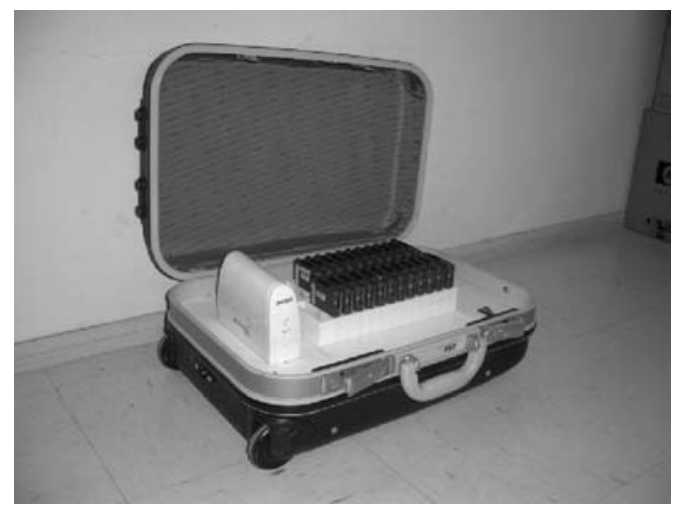

Figure 1. Mobile laboratory. 


\section{PLANS FOR TECHNOLOGY INCLUSION}

Considering that the fundamental objective to reach is to improve education quality, a set of action plans was established, oriented towards resolving/ mitigating the points mentioned above, in order to include technology in the educational process as smoothly as possible.

\section{Plan for the socialization of the technology}

With the aim of obtaining support and commitment from the participants a promotion program directed at the different levels of the academic staff hierarchy was developed. This included separate projects to be presented to deans, heads of departments and academics (the teachers). The program focused on promoting the benefits of the technology that would be used and addressing the concerns perceived for each group of participants. This plan aimed to mitigate the factor 1 .

\section{Plan for the selection of the academics}

Considering that the inclusion of technology and its effectiveness depend, to a large extent, on the interest and commitment of the participating teachers, specific teachers were invited to participate. Teachers that were invited taught courses that carried significant weight within the degree program and that historically had a low pass rate, and had a "pro-technology" profile with regard to the personal motivation for using technology. This plan aimed to mitigate factors 1,2 and 4.

\section{Plan for the training of teachers}

A training program was designed that considered technological and pedagogical aspects. For this, there were two training sessions: the first aimed to introduce and use the technological platform in the development of educational content, and the second aimed at the application of the technology in the classroom and the subjacent pedagogical model. Through the training the teacher was provided not only with the technical knowledge required for the platform but also the skills for the development of the educational material and practices to employ in the classroom, based on the subjacent pedagogical model. This plan aimed to take into account factors 2 and 4 .

\section{Plan for the training of technical assistants}

With the objective of providing a better support service, training programs were also developed for the technical and educational aspects of the platform. These programs were similar to those for the academics but with a different emphasis. Thus the technical assistants were enabled to be partner of the teacher, both in the development of activities and their implementation in the classroom. This plan frees the teacher to have the pressure of complex technical knowledge, and aims to directly mitigate the factor 2 .

Plan for application and support

A plan was designed to support the teacher at all times, both inside and outside the classroom. This help for the teachers included:

- Administration of the necessary resources (designation of use).

- Maintenance of the equipment in a functioning state.

- Transport of the equipment to the classroom.

- Support for the creation of educational material, generation of activities and obtaining reports.

- Technical support for the activity as it is carried out in the classroom.

This plan supports the previous plan and therefore was expected to mitigate the factor 2 .

\section{METHODOLOGY}

It is considered that the effectiveness of implementing the set of plans designed for the inclusion of the technology platform is directly related to achieving improvements in the results of the educational process. In this context it was taken as the main outcome to assess, the percentage of students passing the course.

In order to ensure that improvements are attributable to the planned use of technology, the design of the methodology considered that the results obtained by the teacher should be comparable (at least) with his historical performance in the course and that the application should be under real conditions, this is, not to intervene in factors such as: set and size of the course groups and the evaluation system.

On the other hand, educational processes are social phenomena, therefore, the application of research methods in classical form, are not fully achievable [11]. Thus the methodology was as follows: 
- The study design is quasi experiment.

- The study groups were complete courses whose teachers chose to participate voluntarily.

- For reasons to do with academic procedures, and fairness to the participants, the classes were not divided into experimental and control groups. Because the study is conducted in real conditions, making the separation of control and experimental groups can give rise to claims. For example, if the use of the platform improves the performance of experimental group, the control group can feel in disadvantaged.

- To determine the existence of improvements, the technological platform was used on repeated occasions over time to cover as many possible samples (according to the plans). The average performance per course of ongoing groups that used the platform was compared to historical performance that had the teacher in the course and the historical performance of the course without technology.

- The application environment was the classroom.

- The type of instrument and the evaluation methodology applied to the students were the same that the teachers have historically applied in the course.

- The results were analyzed using a t-test to measure the differences between groups and Cohen's d to determine effect size. The Cohen's $d$ is used to measure the strength of the relationship between two variables. It is often useful to know not only whether a relationship is statistically significant, but also the size of the observed relationship. The effect size measure could then result in a insignificant (less than $0,20)$, small $(0,20$ to 0,49$)$, medium $(0,50$ to 0,79 ) or large (more than 0,80 ) effect.

\section{RESULTS}

As a result of the application of the plans and the subsequent execution of the methodology described above, there was learning benefits connected with the educational process and also with the inclusion of technology, as presented below.

\section{Education-related learning}

The mobile technology platform was used with courses from the Faculty of Science and the School of Engineering, as indicated in Table 1 also it shows the courses and the numbers of students using technology.

Table 2 shows the pass rate for the courses with the use of technology compared with the pass rates for the same course with the same teacher from the previous year, and for the historical record of the course. As can be seen from the table, the use of technology improved the results in all courses. These results were analyzed using a statistical t-test and these differences were found to be significant. In addition, the values was obtained of application of a Cohen's d test indicated the existence of a strong correlation between the application of the technology and the improvement in the results, as indicated in Table 3.

\section{Plans-related learning}

The design of the plans resolved a number of the problems predicted by the literature. However, in carrying out the project, a number of different factors were found to be relevant, which could be important to consider in other contexts:

- The plan for socialization of the technology also allowed information to be obtained regarding prejudices, acceptance, rejection, conditions, needs, etc. that the different participants had regarding the eventual use of the technology platform. This information was fundamental in the design of the remaining plans. For example, it became evident that the Mathematics and Physics professors rejected the technology because the pedagogical resources provided by the platform (multiple choice questions) were inadmissible in their discipline. For other teachers, the fact that the platform was administered by a third party provoked a rejection because the material generated could be copied and used by others without their authorization. Furthermore, the use of a type of technology from a particular brand also provoked suspicion that was not just academic.

- Taking into account what mentioned above and other considerations, the plan for selection of the teachers based on volunteers worked well, as the teachers were motivated and prepared to meet the challenge. However, sudden problems with the functioning of the technology rapidly produced a loss of confidence and if there had 
Table 1. Courses that included technology.

\begin{tabular}{|c|c|c|c|c|}
\hline Year & Semester & Course & Degree program (Major) & $\begin{array}{l}\text { Number } \\
\text { students }\end{array}$ \\
\hline \multirow{2}{*}{2004} & \multirow{2}{*}{ II } & General Chemistry II & Laboratory Chemistry & 41 \\
\hline & & Physical Chemistry II & Laboratory Chemistry & 27 \\
\hline \multirow{9}{*}{2005} & \multirow{5}{*}{ I } & $\begin{array}{l}\text { Foundation course in Computer } \\
\text { programming }\end{array}$ & Computer Engineering & 23 \\
\hline & & General Chemistry I & Laboratory Chemistry & 27 \\
\hline & & General Chemistry I & Chemical Engineering & 21 \\
\hline & & General Chemistry & Radiology & 32 \\
\hline & & General Chemistry & Medical Laboratory Technology & 46 \\
\hline & \multirow{4}{*}{ II } & General Chemistry II & Laboratory Chemistry & 42 \\
\hline & & Physical Chemistry II & Laboratory Chemistry & 36 \\
\hline & & General Chemistry II & Chemical Engineering & 16 \\
\hline & & General Chemistry I & $\begin{array}{l}\text { Pedagogy in Biology, Chemistry } \\
\text { and Natural Sciences }\end{array}$ & 48 \\
\hline \multirow{3}{*}{2006} & $\mathrm{I}$ & Management Information Systems I & \multirow{3}{*}{ Industrial Engineering } & 34 \\
\hline & \multirow{2}{*}{ II } & Management Information Systems II & & 36 \\
\hline & & Systems Theory & & 26 \\
\hline 2007 & I & Management Information Systems I & Industrial Engineering & 14 \\
\hline \multicolumn{2}{|c|}{ Total courses } & 15 & Total students & 469 \\
\hline
\end{tabular}

Table 2. Pass rate for the courses.

\begin{tabular}{|l|l|c|c|c|}
\hline \multicolumn{1}{|c|}{ Course (module) } & Degree program (Major) & $\begin{array}{c}\text { \% Pass rate } \\
\text { with mobile } \\
\text { technology }\end{array}$ & $\begin{array}{c}\text { \% Pass rate } \\
\text { for teacher } \\
\text { previously }\end{array}$ & $\begin{array}{c}\text { \% Pass rate } \\
\text { for the course } \\
\text { historically }\end{array}$ \\
\hline $\begin{array}{l}\text { Foundation course in } \\
\text { Computer programming }\end{array}$ & Computer Engineering & 82.6 & 61.7 & 65.5 \\
\hline \multirow{2}{*}{ General Chemistry I } & Laboratory Chemistry & 55.6 & 37.7 & 38.8 \\
\cline { 2 - 5 } & $\begin{array}{l}\text { Pedagogy in Biology, } \\
\text { Chemistry and Natural } \\
\text { Sciences }\end{array}$ & 47.9 & 20.5 & 24.4 \\
\cline { 2 - 5 } & Laboratory Chemistry & 76.2 & 35.7 & 38.8 \\
\hline \multirow{2}{*}{ General Chemistry II } & Laboratory Chemistry & 68.3 & 64.9 & 64.9 \\
\cline { 2 - 5 } & Chemical Engineering & 81.3 & 72.2 & 64.9 \\
\hline \multirow{2}{*}{ Physical Chemistry II } & Laboratory Chemistry & 63.0 & 56.5 & 56.5 \\
\cline { 3 - 5 } & Medical technology & 75.0 & 56.5 & 56.5 \\
\hline General Chemistry & Radiology & 91.0 & 81.3 & 70.9 \\
\hline $\begin{array}{l}\text { Management Information } \\
\text { Systems I }\end{array}$ & & 100 & 94.5 & 78.6 \\
\hline $\begin{array}{l}\text { Management Information } \\
\text { Systems II }\end{array}$ & Industrial Engineering & 100 & 93.3 & 89.9 \\
\hline Systems Theory & & 96.2 & 87.9 & 88.3 \\
\cline { 3 - 5 } & & &
\end{tabular}


Table 3. Comparison of the experimental and control results.

\begin{tabular}{|c|c|c|c|c|c|c|c|c|c|}
\hline \multirow{2}{*}{ Comparison } & \multicolumn{2}{|c|}{ Control } & \multicolumn{2}{|c|}{ Experimental } & \multicolumn{3}{|c|}{$T$ test results } & \multirow{2}{*}{$\begin{array}{l}\text { Cohen's } \\
\text { d }\end{array}$} & \multirow{2}{*}{ Interpretation } \\
\hline & $\mathbf{M}$ & SD & $\mathbf{M}$ & SD & $\mathbf{t}$ & df & $\mathbf{p}$ & & \\
\hline $\begin{array}{c}\text { Teacher's } \\
\text { previous results } \\
\text { v/s } \\
\text { Using technology }\end{array}$ & 63.6 & 23.8 & 78.1 & 17.2 & 1.72 & 20.00 & 0.05 & 0.70 & $\begin{array}{l}\text { In both cases, the } \\
\text { results obtained } \\
\text { are significant } \\
\text { and there is a }\end{array}$ \\
\hline $\begin{array}{c}\text { Course previous } \\
\text { results } \\
\text { v/s } \\
\text { Technology }\end{array}$ & 61.5 & 20.0 & 78.1 & 17.2 & 2.18 & 21.50 & 0.02 & 0.89 & $\begin{array}{l}\text { between the use } \\
\text { of technology and } \\
\text { the improvement } \\
\text { in the results. }\end{array}$ \\
\hline
\end{tabular}

not been a quick response to solve the problems, the teachers would have abandoned the project. Although the teachers were committed to the project, there were situations that made them doubtful about its continued implementation, such as the lack of some type of recognition or special consideration of the time they had invested (in training, developing a question base and activities, etc.), and the uncertainty as to whether they would be teaching the same course the following semester.

- The training in the technical aspects of the use of the platform as well as in the way to apply it in the classroom, and the technical support given in the logistics (e.g. in taking the equipment to the classroom) and development of the activity in the classroom, were highly valued by the professors.

From the above, it can be established that a process of technology inclusion in the educational process is a multi-factorial problem with four main dimensions: organizational (structure, policies, processes); pedagogical (models and existing practices); technology (maturity, massification, availability); and teacher education (pro-technology, innovators, ability to adapt, change in practices).

Of these four dimensions, the most relevant seems to be teacher education since the availability of a group of teachers that have been trained in the use of new technologies is essential for a transformational process of this nature.

\section{CONCLUSIONS}

With the use of the technology, the academic results of the students were shown to be significantly better than those obtained by students of the same teachers on previous courses and also with the historical performance of the course (with independence of the teacher). It is therefore possible to conclude that the inclusion of technology benefits student results.

From the results above, it can be considered that the introduction of the technology into the teaching programs was successful. The plans for the socialization of the project, the selection of the teachers, teacher training, training of the technical staff and the application and support have contributed to this success. In particular, the training of technical staff in the pedagogical aspects of the technology was essential for the smooth-running of the project.

Regarding the selection of teachers it can be said that they would not take on the challenge of using technology if it is not aligned with their preconceived educational model or if it involves radical changes in their practices. Having worked with teachers who volunteered, facilitated the overcoming of difficulties because they were predisposed to take the risk and highly motivated. However, the results of improvements can't be attributed to this, since one of the comparisons is with the story of the teacher and their characteristics. In this sense, the teacher has been constantly looking for ways to innovate and improve. 
From the first part of the above issue it can be inferred that to promote the use of technology in educational processes is necessary to provide incentives and facilities to offset additional efforts to be made by teachers for this purpose.

Teachers easily become disillusioned by problems or complications that the technology may present.

In relation to the existing four dimensions (organizational, pedagogical, technology and teacher education) in an educational technology inclusion process, the experiment showed that to have a greater chance of success, the decision of which technology use (technological dimension) should be a function of the other three dimensions.

The results obtained from this research are not conclusive since they are based on a single quasiexperimental study. Future research should take other variables into account.

\section{REFERENCES}

[1] K.P. King. "Educational technology professional development as transformative learning opportunities". Computers and Education. Vol. 39, pp. 283-297. Elsevier. 2002.

[2] Sh. Alexander and J. McKenzie. "An evaluation of Information Technology Projects for Higher Education". Institute for Interactive Multimedia University of Technology, Sydney Australia. URL: ww.iml. uts.edu.au/about/staff/lexander/ autexec.html. 1998.

[3] S. Demetriadis, A. Barbas, A. Molohides, G. Palaigeorggiou, D. Psillos, I. Vlahavas, I. Tsoukalas and A. Pombortsis. "Cultures in negotiation: teachers' acceptance/ resistance attitudes considering the infusion of technology into schools". Computers and Education. Vol. 41, Issue 1, pp. 19-37. Elsevier. August, 2003.
[4] J. Voogt, M.P. Almekinders, J. van den Akker and B. Moonen. "A blended in-service arrangement for classroom technology integration: Impacts on teachers and students". Computers in Human Behavior. Vol. 21, Issue 3, pp. 523-539. 2005.

[5] G. Sunkel. "Las Tecnologías de Información y Comunicación (TIC) en la Educación en América Latina. Una Exploración de Indicadores". CEPAL-Serie Políticas Sociales, Naciones Unidas. N ${ }^{\circ}$ 126. 2006.

[6] Sh. Judge and B. O’Bannon. "Integrating technology into field-based experiences: a model that fosters change". Computers in Human Behavior. Vol. 23, Issue 1, pp. 286302. Elsevier. January, 2007.

[7] Ch. Angeli. "Transforming a teacher education method course trough technology: effects on preservice teachers' technology competency". Computers and Education. Vol. 45, pp. 383398. Elsevier. 2005.

[8] G. Doornekamp. "A comparative study on ICT as a tool for the evaluation of the policies on ICT in education". Studies in Educational Evaluation. Vol. 28, Issue 3, pp. 253-271. Elsevier. 2002.

[9] M. Volman, E. van Eck, I. Heemskerk and E. Kuiper. "New technologies, new differences. Gender and Ethnic differences in pupils' use of ICT in primary and secondary education". Computers and Education. Vol. 45, Issue 1, pp. 35-55. Elsevier. August, 2005.

[10] C. Cortez, M. Nussbaum, P. Rodríguez, X. López and R. Rosas. "Teacher Training with face to face Computer Supported Collaborative Learning". Journal of Computer Assisted Learning. Vol. 21, pp. 171-180. 2005.

[11] A.L. Brown. "Design Experiments: Theoretical and methodological challenges in creating complex interventions in classroom settings". The Journal of the Learning Sciencies. Vol. 2, Issue 2, pp. 141-178. 1992. 